\title{
Poetics of Place:
}

\section{A Geocritical Reading}

\section{of Sherman Alexie's "The Search}

Engine", "Lawyer's League", and "Can I Get a Witness?"

\section{Dr. Ahmad Muhammad Al-Sayed Ahmad}

Lecturer in Literature and Criticism, Dept. of English, Faculty of Languages\& Translation, Al-Azhar University 


\section{Abstract:}

This study is divided into two parts. The first part deals with a theoretical outline of the geographical criticism approach. It aims to show the essence and elements of geographical criticism, a completely new critical approach that highlights the relationship between geography and literature, the importance of space, the difference between place and space, and the relationship of man to space. Geographical criticism also focuses on the relationship between real and imaginary places in the study of literature and how it affects the understanding of literary work.

While the second part deals with a practical application of this approach to three short stories of contemporary Indian novelist Sherman Alexey, who are the search engine, bar association, and can I get a witness? The study also examines how the writer uses different types of places and they are the right place, the inappropriate place, and the non-existent, as material elements that help to create multiple and different meanings in literary works.

\section{key words:}

Geographical Criticism - Location - Space - Spatial Studies. 


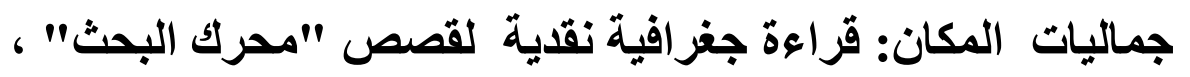

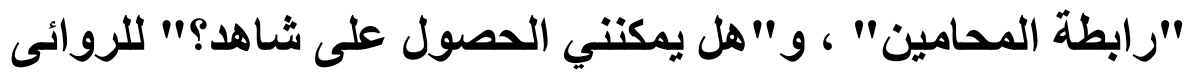

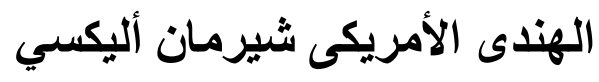

\section{د/ أحمد محمد السبا أحمد}

مدرس الأدب و النقد بقسم اللغة الإنجليزية بكلية اللغات و الترجمة بجامعة الأز هر

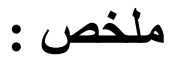

تقع هذه الدراســة في جزأين. يتناول الجزء الأول تاصــيلا نظريا للمنهج النقدى الجغرافى. ويهدف إلى إظهار جوهر وعناصـر النقد الجغرافى ، وهو منهج نقدي جديد تماءًا يسلط الضوء على العلاقة بين الجغرافيا والأدب ، وأهمية المكان، والفرق بين المكان والفضـاء ، وعلاقة الإنسـان بالفضـاء. كما يركز النقد الجغرافى

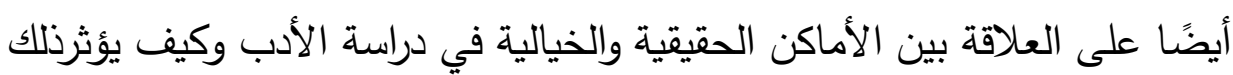

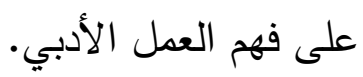

بينما يتناول الجزء الثاني تطبيقا عمليا لهذا المنهج على ثلاث قصص قصـيرة للروائي الهندي المعاصـر شـيرمان أليكسـي ، وهم محرك البحث ، رابطة المحامين ، وهل يمكنني الحصـــول على شـــاهد؟ كما تبحث الدراســـة في كيفية

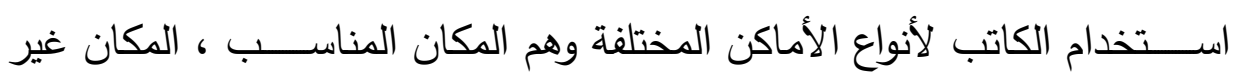
المناســب ، وغير الموجود ، كعناصــر مادية تســاعد على خلق معاني متعددة ومختلفة في ألاعمال الأدبية. الكلمات المفتاحية: النقد الجغرافي - المكان - الفضاء - الدراسات المكانية . 
Generally speaking, it is exotic to write about place/space from a literary point of view. However, place is not confined to the meaning that common people associate it with. Literally speaking, place has many connotations which impart shades of meaning to characters, actions, and may change what people think of whatever they see. Place is not haphazardly used in literature; it is craftily manipulated to convey a message to the readers or audience of literature. It is one of the tools a man of letters uses to direct the reader's attention to an implied or indistinct merit or meaning in his/her work. Real enjoyment lies in discovering whatever devices used to give new meanings to what might be incomprehensible.

Place seems to have been marginalized as it actually received little attention by critics before the twentieth century. Instead, time had occupied critics' thinking until the late twentieth century, which marked the significance place gained. Though time and space are two sides of the same coin in literature as well as other branches of knowledge, they seem to have exchanged value and significance throughout history. Lisa Fletcher underscores the affinity between space and time and calls it the "chronotope". She asserts that "in simple terms, the concept of the chronotope refers to "the intrinsic connectedness of temporal and spatial relationships that are artistically 
expressed in literature" (38). Adam Barrows accounts for the significance time has had before the emergence of spatial studies which focus on the significance of space and how it is manipulated artistically in literature. He states: "In his forward to a volume of essays on geocriticism in 2011, for instance, Westphal begins with the claim that before the spatial turn of the late twentieth century, "time was aristocracy" while space was "only a rough container, a plebian frame for time" (3).

However, the priority either of them gains depends on how much care and effectiveness critics bestow upon each. This does not mean that one of them can do without the other. However, they complement each other. That is, they are interrelated and inseparable. In this connection, Bill Richardson contends that "this self-consciousness reflexivity in relation to spatiality and temporality is an awareness of the intimate connection between the two notions of space and time, neither of which can be conceived of without the other" (6).

Space and place seem synonymous. However, there are some differences between them. Space has received some definitions which make it different from place. Richardson adds, "To take up space is to have a location facing toward or away from other places. Space is, in that sense, relative to place, a location from which and toward which it is. In this 
directedness toward another place, every location is a place contingent to another" (21). Simply speaking, space is that which is borderless, limitless, and directionless. It is a more general term which refers to any spacious vacant place. Richardson defines space and place showing how they are interconnected. He has also referred to two types of space, namely, "ideal and real: ideal with respect to things in themselves, but real with respect to things as appearances. For something to appear to me as an object of perception is for that thing to appear as spatial" (23).

In his Geocriticism: Real and Fictional Spaces, Bertrand Westphal classifies space into urban, social, fictional, imaginary, and real. He also elaborates on Edward Soja's theory of "transform $\{$ ing $\}$ real space into an imaginary place, using the example of Los Angeles, a city that according to a famous slogan is really "seventy two suburbs in search of a city" (89). Westphal then proceeds to shed light on two different perspectives of place, the first is that of Earl Miner who divides fictional place into three types: "the common place which makes no reference to the "real world" referent, the proper place, which refers to a known place in its existing location, and the improper place, which refers to a nonexistent place whose valence is often metaphorical like heaven, hell, 
etc." (101). Then, he hints at Lennard Davis' classification of fictional place into " the actual place, such as Paris in Balzac; the fictious place, such as George Eliot's Middlemarch; and the renamed place, such as F. Scott Fitzgerald's East Egg or West Egg (fictional names for real places in Long Island, New York)" (qtd. in Westphal 101).

All these types of places are raw material elements subject to the use of the man of letters. They can manipulate any one or more of these types of places in a way that helps him or her produce a creative work of art. Any of these types of places are no more than tender clay which allows the writer to formulate it in which way s/he likes to suit her/his plot construction and weaving of events. However, Emily Johansen avers that "a place is made up of various different, often competing trajectories, and also emphasizes the centrality of interpretative practices to spatial relationships" (130).

The differences between space and place are dialectic. However, for geographers and geocritics, space and place are not identical though they may share some common characteristics. Many critics have accounted for such differences, each from a different perspective. On the one hand, Fletcher argues that one of these differences is that space is abstract whereas place is concrete. She contends that "the term 
"locale," then, seems a close synonym for "place" as it is typically distinguished from the more abstract "space" (12). Dustin Crowley, points out that each is different from the other that way. He maintains that "place acts as something to be cherished in ways space cannot. Place is something specific to which we can ascribe meaning, distinctiveness, and value; so "we speak of place-attachment rather than of space-attachment" (22-23). Richardson elaborates on some of the distinctive features of place asserting that

Places are historical spaces as those that embody memories and gestures of future sense. So understood, to move from one place to another is to move not within the form of intuition, but rather within the concrete reality of spaces with meaning, spaces that are bounded by meaning, spaces are historical places (27).

In her Rosario Ferre's "la muneca menor": Fantastic Gendered Space", Angela Martin elucidates how space can be viewed differently to refer to more than an area or place. She states, "space is not an empty void but rather is produced as a result representational thinking by connecting movements to verbal imagination thus creating the spatial concepts of those actions... Spatial representation in narratives is the portrayal 
of social relations within a setting" (51-52). Thus, one of the uses of space is that it can be used as an indication to social relations, class, poverty, wealth, and even more. Martin goes on to elaborate on the significance and function of space saying:

The author must construct a narrative setting that the implied reader can interpret. Traditionally the key components of setting are considered to be time, together with place as coordinates that assign a point on a time-line. But what truly adds the third dimension to a narrative space are the social interrelationships and identities described within the story. The author adds perspective and depth, important to the implied reader in her/his quest for meaning (52.)

Needless to say, space is part and parcel of literature as it is one of its main components. In a nutshell, according to Lisbeth Larsson, "a given space becomes a place and acquires a specific meaning" (9). Geocriticism deals with space not only as part of the setting of a literary work, but also as one of the devices employed in the wok to reveal implied meanings. Concealing meaning in a work of literature is not a breach of the writing rules on the part of the writer, but it is meant to excite the readers' thinking faculty and to arouse suspense in them. 
Linguistically speaking, geocriticism is a compound noun consisting of a prefix 'geo' meaning "relating to the earth or its surface" (Longman Dictionary of Contemporary English 729), and the noun criticism. However, literally speaking, Westphal states that geocriticism "allows us to emphasize the ways that literature interacts with the world and to explore how all ways of dealing with the world are somewhat literary" (x). Accordingly, it aims to elucidate how literature correlates with the world, or how elements such as space can be discussed and analyzed from a literary point of view. Westphal hyperbolically draws a comparison between literature and 'map making' asserting that they "are often analogous, if not identical, to those used in so-called imaginary writing" (x).

Geocriticism is only one among the other common banners under which space can be studied. Robert T. Tally Jr. articulates the different approaches under which space in a work of art can be investigated. He explains "Spatially oriented literary studies, whether operating under the banner of literary geography, literary cartography, geophilosophy, geopoetics, geocriticism" (ix). He accentuates the function of space in literature and the strong relationship that binds the two together. He also emphasizes that space oriented studies whatever it may be called "have helped to reframe or to transform contemporary 
criticism by focusing attention, in various ways, on the dynamic relations among space, place, literature" (ix).

Geocriticism is not only concerned with the investigation of places and spaces with their positive or negative effects on characters and how they direct the action in the work of art; but, it also focuses on the relationship between imaginary places and the real world. In Ecocriticism and Geocriticism: Overlapping Territories in Environmental and Spatial Literary Studies, Tally Jr. and Battista draw upon the basic principles of Westphal's theory of geocriticism. They maintain that these principles or tenets can be summarized as " geocentrism, multifocalization, polysensorality, and stratigraphic perspective" (24). These four propositions constitute the essence and gist of Westphal's geocriticism. They elaborate on how it can be applied to literature. These propositions are summed up in the following lines:

First, for Westphal, geocriticism is a geocentered or geocentric mode of criticism, by which he means that the primary object of study for the geocritic is not literary texts, authors, or genres, but places. A typical geocritical study would focus on a single place (say Paris or Venice or the Mediterranean) and then look at as many textual representations as possible, putting the emphasis on the 
referential relationship between those texts and the place in question. ... Questions of textual mechanics, aesthetic value, and the author's world view are considered, of course, but considered in the light of their referential relationship with realworld place, how they shape our understanding of that place (Tally \& Battista 24).

The other three dimensions seem complementary and overlapping with the first one. As it is evident from the first dimension, the main focus of geocriticism is 'a single place' and it is portrayed and represented in many texts either by the same author or by different authors. Place is, in fact, not only the container of action, but it also formulates and contributes to the development of both action and characters in a work of art. A place imparts new meanings and shades of meanings and other elements of the literary work. However, this does not restrict the geocritic to the study of how place is represented in one or more literary texts. The geocritic is given full freedom to discuss the other elements of a literary work but in correlation with the 'real-world place'.

By multifocalization, Westphal means that the Geocritic should not be confined to the discussion of only one work of art or more by the same author or even belonging to the same 
genre, which itself does not contradict with the first dimension. However, it gives the geocritics enough space to move freely through more than one work. The way a place can be viewed or consulted from many perspectives is what Westphal means by polysensorality. That is, Geocritics can utilize "the auditory, olfactory, and tactile dimensions of place" (Tally Jr. \& Battista 25). It is clearly stated that Geocritics can use their different senses to investigate places in works of literature.

The fourth dimension proposed by Westphal is called stratigraphic. It is concerned with the investigation of recollected memories and histories about places as they are represented in literature. It is a kind of historicizing geographical places through literature. Tally Jr. and Battista state that "stratigraphic logic, then, provides a way to examine time (histories or memories) in geographical spaces through literary texts that simultaneously confuse and illuminate spatiotemporal dimensions" (43). All of these propositions or dimensions serve the end of investigating the significance of place in literature.

One more definition that sums up the essence of geocriticism is that it "is a study of space that explores "real" places and their relationship to fictional or imagined places. The reverse is also true: fictionality allows us to understand these 
"real" places in multidimensional ways" (Tally Jr. and Battista 40). What this definition adds is that fictional places can be a guide to studying or getting information about real places. That is, simply speaking, geography and literature overlap in the sense that one can study geography through literature and read literature geographically. Lindsay G. Pettee's definition of geocriticism does not go far beyond Battista's definition. He states that "Geocriticism therefore aims to explore the spaces created in literature through the interaction between reality and fiction" (2). Thus, the function of the geocritic can be said to "approach analyzing a text by first focusing on its specific place-geographic location, landscape, bioregion, or environmental- instead of on a writer, text, or historical context" (Qtd. in Tally Jr. and Battista 39).

Geocriticism and spatial criticism seem synonymous since both investigate fictional as well as real places in literature. Adams Barrows pinpoints the scope of their study as not " limited to the spaces of the so-called real world, and it sometimes calls into question any too facile distinction between real and imaginary places, as it frequently investigates what Edward Soja has referred to as "the real-and-imagined" places we experience in literature as in life" (vii). 
Edward Said is one of the eminent figures who adopted geocriticism and spatial studies. Tally states that "Said is perhaps best known for his contributions to postcolonial studies, which, as an interdisciplinary field, has been at the forefront of geocritical or spatial literary theory" (4). As both trends seem to be identical to Edward Said, he blends them together. That is, "Said's larger body of work blends geospatial conception of the work the individual critical consciousness with a notion of collective action inherent in his anti-colonialist critiques" (Tally 11).

Sherman Alexie was born in Wellpinit in 1966. He grew up on the Spokane Indian Reservation in eastern Washington State. He is an erudite and prolific writer who consecrated his life and literary oeuvre to the ills of his society, Native Americanism, and how Native Americans struggled against the white American's mainstream. He wrote poetry, short stories, and fiction which reflected Indian Americans' myriad troubles and difficulties on the reservation. He highlighted some realistic issues such as tribalism, poverty, illiteracy, and alcoholism. Patrice E.M. Hollrah states that Alexie wrote about some other issues concerning the reservation and Native Americans. Accordingly, "Alexie's writing is known for, among other things, portraying the realities of life for 
contemporary reservation and urban Indians- unemployment, poverty, alcoholism, death, humor, popular culture, history, and anger" (121).

Alexie's literary oeuvre ranges from poetry to short stories and fiction. He published his collection of poetry entitled The Business of Fancy Dancing. He also wrote I Would Steal Horses, a collection of poetry (1992), Smoke Signals, a film, (1998), The Summer of Black Widows (1996), One Stick Long, a collection of poetry, (2000), The Toughest Indian in the World, short stories, (2001), Ten Little Indians, short stories, (2003), Dangerous Astronomy, a collection of poetry, (2005), The Absolutely True Diary of a Part-time Indian, young adult literature, (2007), and he published Flight, a novel, in 2007, and War Dances (2009), (Connette 5). Moreover, he won numerous awards such as The Audience Award at the Sundance Film Festival in 1998, and The National Book Award in 2007.

Alexie opens his Ten Little Indians with a short story entitled "The Search Engine". It, as Ladino says, is "an instructional tale that teaches readers how to approach the rest of the book by setting up key issues for us to track" (40). He introduces Corliss Joseph, the major character in this short story, as "a rugged individual... a poor kid and a middle class 
Indian" (SE 5) who lived in the Spokane reservation till she "had attended the Spokane River High School" (SE 3). Though Corliss moved to study later in Seattle, she managed to overcome the burdens of ethnicity and tribalism.

Alexie manipulates space to shed light on his characters' actions, habits, and traditions. So, he correlates the Spokane reservation with Native American traditions such as "sacred ceremonies and conventional dances and rituals" (Korsmo 33). The Spokane reservation represents Indianness with all its characteristics which signify the real life of Native Americans. Hence, space is one of the main constituents of the Native American identity. Daniel Grassian shows how the reservation negatively affects Indians and how Corliss manages to escape such barriers by studying in Seattle and getting rid of the traditions of the reservation life. He contends that:

Corliss has conflicted feelings about Indians, reservation, culture, and rather than solely blaming mainstream American culture, as she had been taught to do while growing upon the reservation; Corliss also implicates Indians as being complicit in their economic and personal impoverishment due to their gradually accepted loss of self-sufficiency (Qtd. in Korsmo 40). 
Corliss's rebellion against the shackles of the reservation life is explicit in her attitude towards the white people, and her inclination to read poetry relevant to city life in Seattle.

In "The Search Engine", Alexie stresses the importance of the relationship between Corliss and space in various situations. Having read one of Harlan Atwater's poems in which he presents his experience of swimming in the river, Alexie depicts Corliss's feelings of crossing the "Little Spokane River" (SE 10) and unveils how the various places Corliss passes by in the river have their effects upon her. He narrates, "she had been in the physical and emotional places described in the poem. She'd been in the same places where Harlan Atwater had been, and that made her sad and happy" (SE11). Alexie elaborates on the correlation between man and space and proves how, positively or negatively, spaces can have effects upon a character.

Space has its effects on some characters and their careers in this short story. Harlan Atwater who "grew up in Wellpinit, Washington, on the Spokane Indian Reservation in eastern Washington State" (SE 12) was influenced by this place where he was born and grew up. Atwater tells how the Reservation 
affected his career as a poet. In an answer to a question, how did you start writing? Atwater said:

Well, coming from a culture where the oral tradition is so valued, and where storytelling is an everyday informal part of life, I think I was born and trained to tell stories, in some sense. Of course, this country isn't just Indian, is it? And it's certainly the farthest thing from sacred. I'm the child and grandchild of poor Indians, and since none of them ever put pen to paper, it never occurred to me I could try to be a poet. (SE12)

The Spokane reservation, as one of the main places used by Alexie in his short stories, has a dual function. It is "both a positive place that stresses survival and also a negative place that embodies many of the problems of tribal communities. The reservation should be read as an imagined space- a fictional account of many of Alexie's own experiences" (Baxter 166). Such positivity and negativity, which are highlighted in different parts of his fiction, have their own clear impact on the trajectory of most of Alexie's heroes.

So, the environment where Alexie grew up formed his character and implanted in him the skill of telling stories which he later developed by taking "a poetry class with Jenny Shandry" (SE 12) where he read hundreds of poetry books that 
finally qualified him to write poetry. This elucidates how Alexie's characters "own the ability to move between the different places of the reservation and discern which elements of reservation life will be acceptable within the mapping process" (Connette 29). In addition, his characters manage to go beyond the confines of the reservation to experience life in new spaces and environments.

In an answer to another question, Atwater relates the creative writing of a poem to space as if it is a source of inspiration: "What is your process like for working on a poem? It is all about ceremony. As an Indian, you learn about these sacred places. Sometimes, when you're lucky and prepared, you find yourself in a sacred place, and the poems come to you" (SE 13). Space is not just a form or container in which the incidents of a specific work take place. Rather, it is not less important than the plot or any of the characters of the work as it turns the tone of such a work into either positive or negative and controls the flow of incidents. Alexie employs the reservation, one of the essential places in his fiction, as "a center of polarity between western influence and Indian culture and lessens the tension between cultures by making his characters active participants in cultural exchange" (Connette28) 
In her first phone call to Atwater, Corliss refers the readers of this short story from the physical or material space to the hypothetical spatial sphere of Atwater's mind. In order to catch the call, she asks him "Are you in the reservation of your mind?" (SE 14). A question that keeps Atwater silent for sometime thinking before he replies or hangs. Reservation is a place where Indians used to live; it also symbolizes their customs, traditions, and tribal ethics. So, using it in this sense enhances Corliss's successful attempt to find that great poet, in her eyes, having kept searching for him for a long time.

In Corliss's search journey for Atwater, Alexie highlights man-space relationship and articulates how people are affected by the places they live in. Corliss holds a comparison between Seattle and Spokane, briefly showing how amazing Seattle is and how astonished she was. Mapping the cartography of the area, Alexie writes:

Eighteen hours later, Corliss stepped out of the Greyhound in downtown Seattle and stared up at the skyscrapers. Though it was a five hour drive from Spokane, Corliss had never been to Seattle... the big city felt exciting and dangerous to her. Great things happened in big cities. She could count on one hand the amazing people who had grown up in Spokane, but hundreds of superheroes had lived in Seattle... 
you could stand on Houston Street in Lower Manhattan, throw a rock in some random direction, and hit a great poet in the head. If human beings possessed endless possibilities, then cities contained exponential hopes. (SE 16)

Corliss's journey from the Spokane reservation to Seattle is not just a journey between physical and real places. These real places have symbolic connotations. Elina Sonne contends that "it seems logical, then, to regard the journey out of the reservation as a journey out of the past into the contemporary world" (29).

Man-space correlation is that of form /content type. That is, they are inseparable. Man melts in space till he/she becomes part and parcel of it and reflects most, if not all, of its features. Space, on the other hand, represents and is represented in man's behavior, traditions, education, and culture. Seattle vs. Spokane elucidates how the people who live in either place are somehow different from their counterparts. Alexie manages not only to underscore such a man-space correlation, but sometimes gives space some 'human characteristics' as well. Connette asserts that:

By giving the reservation human characteristics, Alexie makes it an active 
participant in the dialogic of the text. Dialogic, in this case, references the

dialogism of Russian theorist Mikhail Bakhtin, which Clark and Holquist

define as, "an account of relations between people and between persons

and things that cuts across religious, political, and aesthetic boundaries."(35)

Though this short story tackles various places such as Macdonalds, the used book-store, Atwater's house, the Spokane Reservation, and Seattle, two places have the greater effect on the course of events: Seattle and the Reservation. One of the minor effects of the used-book store on Corliss is dizziness. She was fascinated with the view of the old books in the store regardless of their bad smell. The whole scene is portrayed as follows:

She walked through the bookstore that smelled of musty paper and moldy carpet. She scanned the shelves and read the names of the authors printed on the spines of all lonely, lovely books..., but Corliss felt like old books were sentient beings that listened and remembered and passed judgment. Oh, God, 
I'm going to cry again, Corliss thought, I'm losing my mind in a used-book store (SE 23).

Alexie emphasizes the correlation between man and space. Asking Atwater whether he is Indian or not, Corliss contends that everybody should carry some of the features, if not all, of the place where he was born or raised in. She sets herself an example who, henceforth, feels like a nomad. Answering this question, Corliss claims:

We who were once indigenous to this land must immigrate into its culture. I was born one mile south and raised one mile north from the place on the Spokane River where the first Spokane Indian was ever born, and I somehow feel like nomad, so Harlan Atwater must feel completely lost. (SE 25)

Consequently, she deduces that Atwater feels like completely lost as he lacks the sense of belonging to India, which he usually mentions in his poetry. Writing poetry about India is just a means for Atwater to feel belonging, "to feel more Indian" (SE 26). To assert his love and belonging to native land, Atwater says "I started imagining what it felt like to grow upon the Reservation" (SE 26). So, many human values such as love and belonging can grow as a result of one's relatedness to a specific place. Jeff Berglund thinks that Corliss is 
"disappointed to find not only a man who was coerced to ply Indian in the late 1960s but also one who has no interest or connection to his tribal people" (254).That is, spatiality seems to be one of the constituents of the characters of human beings. Hence, a man living in the city shows behavioral characteristics different from another who lives in a small village or an uncivilized area.

Place and culture are interrelated as well. One's place nearly refers to his/her culture. But in the case of Corliss who was born and raised on the reservation on the Spokane River, it seems totally different. As a Spokane, Corliss should not be interested in learning or reading poetry; she would rather become an ordinary nomad the same as the other Spokane are. However, she takes off the cloak of the Indian woman and occupies the space of a cultured European woman, who is interested in reading, learning, and appearing smarter than Spokane Indian women. She transcends the boundaries of Indianness. Of Corliss, Alexie states: "She knew she wasn't supposed to be in college and she wasn't supposed to be as smart as she was and she wasn't supposed to read the books she read and wasn't supposed to say the things she said. She was too young and too female and too Indian to be that smart" (SE 26). 
"The Search Engine" ends with a warm meeting between Atwater and Corliss. Atwater remembers his early childhood on the Reservation and how he was very poor. This can be summed up in the space/society binary opposition. Space is, in no way, indicative of one's richness or poverty as well as expressive of one's feelings and thoughts. Alexie succeeds in highlighting such a connection, in his Ten Little Indians. He often associates his characters with spaces relevant to their positions, social classes, and even their thoughts and education. His nifty depiction of such places geographically and culturally corresponds to real places to the extent that the demarcating lines between the fictional places in his The Search Engine and real places are almost unrecognizable. In The Search Engine, Alexie let Atwater express such a relationship between space and his status saying: "it's hard," he said. He looked down at his ... as he spoke. "I mean I grew up so poor on the Reservation, you know?" (28).

In Alexie's second short story, entitled "Lawyer's League", of his collection Ten Little Indians, space plays a pivotal role in the formation of his characters and in the development of events as well as an incarnation of the real places depicted in this fictional work. Richard, the hero of the Lawyer's League, is a young man whose father is "An African 
American giant who played defense end for university of Washington ,... and a mother (who) petite Spokane Indian ballerina who majored in dance at U-Dub" (LL 34), who usually called himself " a graceful giant” (LL 34). Alexie sets the action of this short story in Seattle. The hero "grew up in Seattle,... and attended North Seattle Community College" (LL 34). Again, Alexie depicts Seattle as a city where university life, education, sports, and all other facilities are available and which actually affects those living in it.

Due to his half Indian origin, Richard graduates and works as 'Locke's executive liaison to Washington State's twenty-nine Indian tribes" (LL 34). Hence, he has to negotiate with Indian tribes which he describes as follows: "Quite a few of the State's most powerful Indian men and women are functionally illiterate" (LL 34). Here, Alexie again stresses the relationship between illiteracy, poverty, and simplemindedness and the reservation where Native Americans live. He does not change roles for the places he portrays in his collection. This is one of the two sides through which Alexie usually depicts the reservation; it is the negative side which reflects the ills of that place. Baxter states that "the reservation in his (Alexie) fiction is both a positive place that stresses survival and also a negative place that embodies many of the 
problems of tribal communities" (166). Richard's half-black and half-Indian origin encourages him to be a brilliant politician, a senator, and then a president of the USA. This objective actually emanates from his feeling of the marginalization of his Native American tribes.

Place is both a landmark and a turning point in Richard's life. So, a meeting for dinner at "a wonderful French restaurant down near Pike Place Market in Seattle" (LL 35) gives Richard his spark of life. At this restaurant, he meets "five lawyers who might be described as two married white couples and a single white woman," (LL 35). He feels attracted to a white woman namely, Teresa, and thinks of getting married to her. However, he gets frustrated when he, for the first time, thinks how such a marriage can deter his political career and terminate his ambition of becoming a senator. Of the impact place may have on one of the characters in a literary work such as Richard, Larsson says, "it is the city's open spaces that the vital meetings take place and important decisions are made" (48). Here, Richard whispers:

A simple politico dinner had presented me with a profound moral dilemma. It was a wonderful opportunity for me to self-define. Were my eccentric needs as an individual 
more important than the country's desperate need for excellent relationship? I knew I would never achieve my full potential as a public servant if I married a white woman. I would lose votes each time I kissed my wife in public (LL 39).

So, Richard has to choose either to marry Teresa or to achieve his goals of becoming a senator and keeping his tribe's votes and, finally, he takes the decision of abandoning Teresa for the sake of his ambition.

Alexie handles places for different purposes. In his collection, each place has a role to play and symbolizes a nifty hidden purpose. As the restaurant is a place where Richard can actually recognize his true nature and how to keep his future position and achieve his goals, "the small gym the lawyers rented once a week at St. Joseph's Elementary School" (LL 40) to play basketball is a real symbol for the conflict between Richard and Big Bill. Big Bill, a white American Prosecutor, seems to symbolize the white American who has all the rights Richard and his Native American tribes are deprived of. Big Bill is the only one in the two teams who is presented as a good hoopster or basketball player who gets very angry when Richard becomes his rival. Richard describes Big Bill's reaction against his play at the court that way: 
Angry and righteous, I leaped high for the dunk higher than I had been in many years and rose a good foot above the rim, but dropped the ball down through the net instead of dunking it.

"No baskets!” Bill screamed.

"What?" I asked.

"There is dunking!" he screamed at me, face-to-face.

"That wasn't a dunk" I screamed back and pushed him away. He pushed me back. I couldn't believe it. I was ready to fight, though I had not been in a fist fight with in twenty-six years" (LL 41).

This scene symbolizes the conflict between white and colored Americans. The white American wants to be the boss, the winner, and the master. He does not like to have non-white equals or rivals. Alexie's Richard, who manages to transcend the boundaries of the Indian reservation with its poverty and frustrating impediments, feels trapped in "the reservation of the mind that can be used to describe a worldview imposed upon Indians by the United States" (Baxter 73). That is, he flees the Indian reservation to fall in the trap of the White American's reservation, which stresses the lines of demarcation between the White American and the Indians. 
Alexie's choice of places is both denotative and connotative. The basketball court can easily be denotatively grasped as nothing more than a place where basketball players play and compete. However, in this context, it can connotatively be understood as a battlefield between white Americans impersonated by Big Bill and Native Americans and colored people on the other side represented by Richard. Big Bill's bloody nose and face, resulting from Richard's punch, assures the scene of the symbolic battlefield. Having imagined himself in a court trying to defend himself, Richard says: "yes, I punched Bill in the face, and I must admit that it felt good and true. Of course I broke his nose. What else was I supposed to do? He was a racist" (LL 44). Depicting Big Bill as a racist who loses the combat against the Native American, Alexie craftily sheds light on the white characters in defamatory way, throughout his literary oeuvre. According to Kedong Liu: "Alexie presents white characters in such a way that the reader sees them as vulnerable, womanish, or impotent. In a way, Alexie otherizes the white or simply he puts whites in an American lens, to help white characters rethink their roles and take Indians as their equals" (106).

Alexie's "Can I Get a Witness?", the third short story discussed in this paper, begins with the heroine, a fifty-year-old 
native American, who, like some of Alexie's heroes, was born and raised on the Spokane Indian Reservation, eating her lunch in "a postcolonial wonder house" $(C I G W 45)$ in Seattle. This restaurant depicts the cultural clash between Americans and non- Americans and shows how bloody and destructive such a clash is.

At the moment the heroine is waiting for the waiter to return her credit card, there takes place a bomb attack in front of the restaurant, which causes the death and injury of many people inside and outside the restaurant. The bomber is actually not American. Alexie describes him as: "A Syrian American born in Seattle and raised in upper-class comfort by his Muslim father and catholic mother. He had graduated from Lakeside Upper School and Seattle University, and had been working toward his Ph.D. in economics at the University of Washington" (CIGW46)

The bomber's ethnicity refers to anti-Americanism though he had never shown such sentiments.

Alexie sets most of the incidents of this short story in this restaurant. This restaurant is not portrayed to play its role as a place for serving food for money, but to be the crime scene 
of such a terrorist attack which results in the death and injury of a lot of people. Illustrating this scene, Alexie says:

Outside the restaurant, three people were killed by the initial explosion, and two others died during ambulance ride to the hospital; another thirty-seven were injured. Inside the restaurant, twenty three people were killed instantly, and fourteen more would die within the next twenty four hours. Forty one people survived the blast, but thirteen of them suffered serious injuries that required long hospital stays and intensive rehabilitation (CIGW 45).

The restaurant, a place for nourishing one's life by serving food, changes from being a life giver to a life terminator. Changing the role of such a place, from being a lifeprovider into being a death provider, does not seem to be the only message the author intends to convey. However, it seems that Alexie employs such a blast to refer to or symbolize the September $11^{\text {th }}$ bombing of the World Trade Center, which turned into a hell and death provider resulting in the demise of a large number of people. The symmetry Alexie employs here to depict such a catastrophe highlights the significance of place and the role it is assigned to and how changeable and destructive its roles may be. 
One of the connotations of place Alexie proposes in this short story is that of associating terrorism with specific places. Alexie, underpinning the qualities of the rural, natural, and peaceful life of the reservation, was bold enough to attach terrorism to modern cities. This implies an indirect comparison between the Spokane reservation, which Connette describes as "established lands for tribal sovereignty" (5), and Seattle with people of various ethnicities whose loyalty may be consecrated to other places. Connette substantiates that "the sacred space is the tribal value and loyalty to the reservation; his profane space is the exposure to pop-culture and mainstream society" (50). This is how space can be traced in Alexie's fiction; it is either sacred or profane. The only sacred space for him is the Spokane Indian reservation, whereas all other spaces are profane in his eyes. One of the rescuers reaches the exploded restaurant and sees an injured woman whose complexion, eyes color, hair color seem to be non-American, which leads him to think of her as the person who carried out the blast. Of the rescuer, Alexie states: "He looked at this woman with her long black hair and brown skin and brown eyes, and wondered if she was Iraqi or Saudi Arabian or Afghani. Maybe she was a Muslim terrorist who had exploded the restaurant and was using him to make her escape" (CIGW 50). 
Though Alexie, the narrator of this short story, is a native American who himself sometimes suffered racism and apartheid, he thinks of Arabs as terrorists and Arab countries as the birthplace of terrorism, exactly as Americans and Europeans do.

The rescuer's apartment is the second place where the action of this short story is set and which seems less important than the crime scene. The significance of this apartment lies in the fact that it is near the exploded restaurant and the locus where both the rescuer and the injured lady talk about their own lives and the victims of the explosion and remember the September $11^{\text {th }}$ attack on the World Trade Center and how many people were killed and how they used to live before this incident. The rescuer "led her (the injured woman) to his apartment building in Pioneer Square and three flights up to his place" (CIGW 58).

This short story seems to have been written for the purpose of narrating what happened on September $11^{\text {th }}$ and the death toll which it resulted in. The action moves quickly from the blast at the restaurant to the collapse of the towers of the World Trade Center as if the blast at the restaurant was no more than a prologue to what happened on September $11^{\text {th }}$. The collapse of the World Trade Center towers was not depicted 
only as a collapse of a specific building, but it was also used symbolically to refer to the collapse of evil people whose lives were of no benefit. The lady shows how such a collapse though it resulted in financial loses and was a fiasco, was a severe punishment to a group of evil-doers. She states: "Let's say twelve hundred men died that day. How many of those guys were cheating on their wives? A few hundred probably. How many of them were beating their kids? One hundred more, right? Don't you think one of those bastards was raping his kids?" (CIGW 59).

This is how Alexie portrays the collapse of a building as bringing about the death to thousands as a capital punishment and as an end to some wrong deeds. He manages to correlate place with his heroine, and the animate with the inanimate, and to prove that what one may think of as a loss may in fact be a gain. Alexie's portrayal of the Native American lady, the heroine of this short story, who has undergone such terrific moments of the blast, who in fact symbolizes all Native Americans' suffering, has attained praise from critics and reviewers. Amir Hossain contends that "Alexie's poetry, short story, and fiction have been praised by critics, scholars, and reviewers for the realistic portrayals of the Native American experience" (382). Employing realistic places is actually one of 
the nifty techniques which characterize Alexie's fictional works.

Alexie shows how that lady, the heroine of this short story who suffered from her husband's ill-treatment, feels happy at the restaurant, thinking that she is about to die. The lady says:

The biggest thing is, ever since the Trade Center fell down, I have been hoping it would happen to me. I kept hoping I'd be at work or in some shopping mall or theatre when it blew up. So when that bomber ran inside the restaurant and shouted at us, I was happy. I know God has answered my prayers (CIGW 61).

This stresses the fact that the correlation between man and place is powerful. So they are inseparable. Man is born, raised, and buried in place.

In a nutshell, these three short stories articulate a crafty manipulation of spatial characteristics reflexive of people's thoughts and behaviors. Alexie has succeeded in demonstrating that places can be indicative of more than what they appear to be. Places, in Alexie's fiction, are as important and significant as characters. The functionality of place seizes the attention of both readers and critics, with Alexie using four fictional places 
of prime importance in this collection: the Spokane Indian reservation, Seattle, the basketball court, and the restaurant. Each one of these places showers the readers with myriad meanings.

The Spokane reservation serves as both the logo of originality and tribal ethnicity, which all Native Americans, wherever they go, abide by and feel proud of, and the land of poverty, ignorance, oppression, and marginalization. It is also Alexie's sacred place, which is still the source of inspiration, love, peace, and tranquility.

On the other hand, Seattle symbolizes Modern Civilization, modernity, education, and development. Also, Seattle, in many of Alexie's short stories, has a specific level of geographic assimilation to the extent that the characters and events in his short stories seem to be real. As a setting adopted by Alexie, it seems to be familiar to the readers acquainted with the city life since they can visualize some, if not all, of its locations and landscapes.

The Basketball Court validates the conflict between white Americans, who believe they are the masters, the landlords, and the patrons of civilization and modernity, on the one hand, and Native Americans, who manage to escape their 
Indian reservation with its ills to live equally with partner white Americans, on the other. The basketball court, as a place, indicates how each party tries to prove his own rights, which conflict with the others' alleged rights. This results in a cultural clash and a bloody confrontation because of white Americans' racial attitudes.

The final essential place is the restaurant which does not play its role of serving food for money as it is supposed to be. Instead, it becomes the crime scene of a terrorist bomb explosion. The bomber, though presented as the son of a SyrianAmerican Muslim father and a catholic American mother, seems to suffer the burdens of a reservation similar to that of the Indians; a fictional reservation that usually puts him second to white Americans, who are presented as racist and arrogant. Alexie manages to demonize the characters of white Americans in his collection by depicting them as racist, tyrant, and haughty, which leads some Indians to react violently against them.

Having Read Alexie's Ten Little Indians geocritically, one can finally conclude that he has succeeded in correlating imaginary places with real places. This is clear-cut in his portrayal of places in a way that makes readers think of them as 
nothing but real places. Also, his skillful depiction of characterspace relationship proves that he is a distinguished story teller. 


\section{Works Cited}

Alexie, Sherman. Ten Little Indians. New York: Grove Press, 2003.

Barrows, Adams. Geocriticism and Spatial Literary Studies: Time, Literature, and Cartography After the Spatial Turn, the Chronometric Imaginary. New York: Palgrave Macmillan, 2016.

Baxter, Corby J. Indian Humour and Stereotype in Selected Works of Gerald Viznor, Thomas King, and Sherman Alexie. Ph.D. University of Texas, 2012.

Belgrund, Jeff. "The Business of Writing: Sherman Alexie's Meditations on Authorship". Sherman Alexie: A Collection of Critical Essays, ed. Jeff

Belgrund and Jan Rouch. Utah: Utah University Press, 2010.

Connette, Tracey L. Sherman Alexie's Reservation: Relocating the Center of Indian Identity. MA. East Carolina University, 2010.

Crowley, Dustin. Africa's Narrative Geographies: Charting the Intersections of Geocriticism and Postcolonial Studies. USA: Palgrave Macmillan, 2015.

Fletcher, Lisa. Popular Fiction and Spatiality: Reading Genre Setting. USA: Palgrave Macmillan, 2016.

Grassian, Daniel. Understanding Sherman Alexie. South Carolina: University of South Carolina Press, 2005.

Hollarh, Patrice E. M. The Old Lady Trill, The Victory Yell: The Power of Women in Native American Literature. New York: Routledge, 2004. 
Hossain, Amir and Abu-Nayem Sarker. "Sherman Alexie's Literary Works as Native American Social Realistic Projections". European Scientific Journal.

Vol. 12, No. 11, April 2016, pp 381-397.

Johansen, Emily. Cosmopolitanism and Place: Spatial Forms in Contemporary Anglophone Literature. USA: Palgrave Macmillan, 2014.

Korsmo, Janie. 'Leaving the Rez': Indigenizing Urban Space in Selected Short Stories by Sherman Alexie”. Ph.D., University of Central Oklahoma, 2011.

Ladino, Jennifer K. "A Limited Range of Motions?": Multiculturalism, Human Questions. Studies in American Indian Literatures, Fall 2009, Vol. 2, No. 3, pp 36-58.

Larsson, Lisbeth. Walking Virginia Woolf's London: An Investigation in Literary Geography. Switzerland: Springer Nature, 2017.

Liu, Kedong \& Huizhang. "Self-and Counter-Representations of Native Americans: Stereotypical Images of and New Images by Native Americans in

Popular Media". Intercultural Communication Studies xx: $2,2011$.

Longman Dictionary of Contemporary English for Advanced Learners. Uk: Pearson Education Limited, 2010.

Martin, Angela. "Rosario Ferre's 'la muneca menor' Fantastic Gendered Space".

Florida Comparative Studies Journal. Vol. 12, 2010-2011, pp 39-62. 
Home.fau.edu/peralta/web/FACS/genderedspace. $p d f$

Pettee, Lindsay G. Terra Australis Incognita: A Geocritical Analysis of Australian Gothic Literature, M.A. NP., 2015.

Richardson, Bill. Spatiality and Symbolic Expression on the Links between Place and Culture. USA: Palgrave Macmillan, 2015.

Sonne, Elina. Warriors on the Road: Journey Narratives and American Mascluinity in Sherman Alexie's The Toughest Indian in the World. MA.

University of Tampere, 2015.

Tally Jr., Robert T. The Geocritical Legacies of Edward W. Said: Spatiality , Critical Humanism, and Comparative Literature. USA: Palgrave Macmillan, 2015.

Tally Jr., Robert T. \& Christine M. Battista. Ecocriticism and Geocriticism: Overlapping Territories in Environmental and Spatial Literary Studies. USA:

Palgrave Macmillan, 2016.

Westphal, Bertrand. Geocriticism: Real and Fictional Spaces. trans. Robert T.

Tally Jr. USA: Palgrave Macmillan, 2011. 